\title{
Analysis of Critical Thinking Ability in Solving Mathematical Problems in Terms of Student Learning Style
}

\author{
Selvia Nur Afnia ${ }^{1}$, Fariz Setyawan ${ }^{2}$ \\ ${ }^{1}$ Universitas Ahmad Dahlan Yogyakarta, selvia1600006161@,webmail.uad.ac.id \\ ${ }^{2}$ Universitas Ahmad Dahlan Yogyakarta, fariz.setyawan@pmat.uad.ac.id
}

\begin{abstract}
This study aims to analyze students' critical thinking skills in terms of visual, auditory, and kinesthetic learning styles, as well as the factors affecting students' critical thinking skills. As many as three students with visual,auditory, and kinesthetic learning styles were selected from a junior high school using a learning style test in Yogyakarta Indonesia to solve a mathematical problem encouraging critical thinking. Results showed that students with a visual learning style was able to achieve 2 stages of critical thinking correctly, but a little incomplete, namely the basic skills building stage (basic support) and the conclusion stage (inference), while student with an auditory learning style was able 2 stages of critical thinking correctly and appropriately, namely the basic skills building stage (basic support) and the conclusion stage (inference). Meanwhile, student with a kinesthetic learning style was only able to reach 1 critical thinking stage, namely the basic skills stage (basic support). Some factors affecting students' critical thinking skills in solving math problems are identified, namely the weak ability to solve problems related to story problems, the learning styles used by students, and student tendency to only use one method to solve math problems that might come from the teacher.
\end{abstract}

Keywords: Critical Thinking, SPLDV, Learning Style.

\section{Analisis Kemampuan Berpikir Kritis dalam Menyelesaikan Masalah Matematika Ditinjau dari Gaya Belajar Siswa}

\begin{abstract}
ABSTRAK
Penelitian ini bertujuan untuk menganalisis keterampilan berpikir kritis siswa ditinjau dari gaya belajar visual, auditori, dan kinestetik, serta faktor-faktor yang mempengaruhi keterampilan berpikir kritis siswa. Sebanyak tiga siswa dengan gaya belajar visual, auditori, dan kinestetik dipilih dari sekolah menengah pertama dengan menggunakan tes gaya belajar di Yogyakarta Indonesia untuk menyelesaikan masalah matematika yang mendorong berpikir kritis. Hasil penelitian menunjukkan bahwa siswa dengan gaya belajar visual mampu mencapai 2 tahap berpikir kritis dengan benar, namun sedikit kurang lengkap yaitu tahap pembinaan keterampilan dasar (basic support) dan tahap kesimpulan (inference), sedangkan siswa dengan gaya belajar auditory. Mampu 2 tahap berpikir kritis dengan benar dan tepat, yaitu tahap pengembangan keterampilan dasar (basic support) dan tahap kesimpulan (inference). Sedangkan siswa dengan gaya belajar kinestetik hanya mampu mencapai 1 tahap berpikir kritis yaitu tahap keterampilan dasar (basic support). Beberapa faktor yang mempengaruhi kemampuan berpikir kritis siswa dalam menyelesaikan masalah matematika teridentifikasi yaitu lemahnya kemampuan menyelesaikan masalah yang berkaitan dengan masalah cerita, gaya belajar yang digunakan siswa, dan kecenderungan siswa hanya menggunakan satu metode untuk menyelesaikan masalah matematika yang mungkin bersumber dari guru.
\end{abstract}

Kata kunci: Berpikir Kritis, SPLDV, Gaya Belajar.

Tanggal Masuk: 15 Oktober 2020; Revisi: 20 April 2021; Diterima: 24 April 2021 


\section{Pendahuluan}

Keberlangsungan hidup masa depan adalah masalah pendidikan. Menurut Nugroho, dkk [1] bidang studi matematika merupakan salah satu pelajaran wajib yang harus dipelajari di semua jenjang pendidikan. Menurut Rahayuningrum, dkk [2] matematika sebagai salah satu ilmu dasar dewasa ini telah berkembang sangat pesat, baik materi maupun kegunaanya. Sedangkan menurut Andriani [ 3 ] bahwa matematika melatih siswa untuk berpikir kritis, logis, sistematis, dan dapat menyelesaikan masalah yang dihadapinya dalam kehidupan sehari-hari.

Salah satu materi yang dipelajari oleh siswa SMP adalah materi SPLDV (Sistem Persamaan Linear Dua Variabel). Materi ini dipelajari di kelas VIII semester genap. Menurut Febriano [4] materi ini memerlukan keterampilan yang tinggi karena seseorang perlu banyak prosedur yang perlu dilakukan untuk menemukan suatu penyelesaiannya. Oleh karena itu, SPLDV merupakan salah satu materi dalam pembelajaran matematika yang berkaitan erat dengan kemampuan berpikir kritis yang merupakan bagian dari High Order Thinking.

Peran seorang guru mengembangkan kemampuan berpikir kritis bagi siswa termasuk siswa sekolah menengah pertama diketahui penting karena pada tingkat ini proses berpikir siswa mulai berkembang dalam memecahkan masalah. Hal ini sesuai dengan penelitian yang dilakukan oleh Karim [5] yang mengatakan bahwa guru diharapkan memiliki kreativitas dalam menyampaikan materi pelajaran agar menciptakan suasana belajar yang menyenangkan bagi seluruh siswanya. Jika siswa sudah menyukai pelajaran yang diberikan, maka kesulitan dalam memahami materi yang diberikan bukanlah suatu kendala dalam proses belajar mengajar. Kesulitan siswa dalam memecahkan masalah seringkali dibahas oleh beberapa peneliti, salah satunya Mac Gregor dan Stacey dalam Irianti, dkk [6] yang mengungkapkan bahwa siswa kurang memahami dalam memformulasikan persamaan aljabar, meskipun penyelesaiannya hanya menggunakan persamaan linear dua variabel. Padahal menurut Carraher dalam Irianti, dkk [6] penguasaan materi aljabar memiliki peranan penting saat mempelajari matematika.

Dalam membangun pemahaman tersebut dipengaruhi oleh gaya belajar yang dimiliki oleh masing-masing siswa. Dunn dan Griggs dalam Rosmaiyadi [7] mengatakan bahwa gaya belajar merupakan kumpulan karakterisktik pribadi yang membuat suatu pembelajaran efektif untuk beberapa orang dan tidak efektif untuk orang lain. Menurut Setyawan [8], gaya belajar berhubungan dengan bagaimana siswa memperoleh, menyimpan, maupun menggunakan informasi untuk menanggapi suatu tugas atau menanggapi berbagai jenis situasi yang dialaminya. Ketika sudah menemukan gaya belajar yang sesuai dengan dirinya maka seorang siswa akan memudahkan siswa untuk memahami materi yang disampaikan guru. Mereka menyukai informasi yang diterima secara runtut. Ditambah lagi, siswa tersebut suka menulis apa yang dikatakan oleh guru. Karakteristik tersebut merupakan salah satu karakteristik siswa Visual, sedangkan siswa yang memiliki gaya belajar auditori yang mengandalkan kemampuan untuk mendengar. Sari [9] mengatakan bahwa siswa dengan gaya belajar Kinestetik lebih menyukai belajar dengan cara terlibat langsung seperti bergerak, bekerja, dan menyentuh.

Dari hasil pengamatan pada proses pembelajaran di kelas, terlihat siswa mempunyai karakteristik belajar yang berbeda-beda. Pada saat guru menjelaskan di depan kelas, adasiswa yang memperhatikan guru dengan banyak gerak, mereka tidak dapat duduk lama pada waktu proses pembelajaran berlangsung. Tetapi pada saat guru melontarkan pertanyaan, beberapa siswa mampu menjawab pertanyaan yang diberikan oleh guru. Hal ini yang mendasari peneliti untuk mengetahui kemampuan berpikir kritis siswa saat menyelesaikan masalah yang diberikan.

Adapun menurut Siswono [10] berpikir kritis adalah sebuah proses keterampilan berpikir secara efektif untuk membantu seseorang membuat sesuatu, mengevaluasi, dan menerapkan keputusan sesuai dengan apa yang diyakini atau dilakukan. Selain itu, tahapan kemampuan berpikir kritis siswa meliputi elementary clarification (penjelasan sederhana), basic support 
(keterampilan dasar), inference (kesimpulan), dan strategy and tactic (strategi dan taktik) [10]. Bedasarkan tahapan tersebut dikembangkan indikator siswa dalam menyelesaikan masalah yang diberikan.

Oleh karena itu, penelitian ini bertujuan untuk (1) mendeskripsikan kemampuan berpikir kritis siswa ditinjau dari gaya belajar Visual, (2) mendeskripsikan kemampuan berpikir kritis siswa ditinjau dari gaya belajar Auditori, (3) mendeskripsikan kemampuan berpikir kritis siswa ditinjau dari gaya belajar Kinestetik, dan (4) mengetahui faktor yang mempengaruhi kemampuan berpikir kritis siswa dalam menyelesaikan masalah matematika.

\section{Metode Penelitian}

Penelitian ini merupakan penelitian deskriptif kualitatif. Subjek penelitian adalah siswa kelas VIII di sebuah sekolah menengah pertama di Yogyakarta tahun pelajaran 2019/2020. Pemilihan subjek penelitian berdasarkan teknik pengambilan random sampling dan purposive sampling yang mana sampel diambil dari anggota populasi yang dilakukan secara acak tanpa memperhatikan strata yang ada dalam populasi tersebut[11]. Untuk menentukan kelas subjek, peneliti memilih secara acak dan dipilih satu kelas untuk mewakili populasi yang ada. Hal ini dikarenakan kelas yang dipilih tidak ada yang berkategori kelas unggulan. Oleh karena itu, dalam penelitian ini dipilih satu kelas yaitu kelas VIII E. Menurut Sugiyono [12] purposive sampling adalah teknik penentuan sampel dengan pertimbangan tertentu.Pertimbangan tertentu ini, misalnya orang tersebut yang dianggap paling tahu tentang apa yang diharapkan, sehingga akan memudahkan peneliti menjelajahi objek yang akan diteliti [11]. Dalam hal ini, peneliti meminta pertimbangan guru berkaitan dengan pemberian angket gaya belajar siswa. Adapun setelah siswa mengisi angket tersebut, peneliti menganalisis kemampuan berpikir kritis subjek. Variabel yang diteliti adalah kemampuan berpikir kritis.

Teknik pengumpulan data yang digunakan adalah teknik tes dan teknik non tes. Teknik tes berupa angket dan tes kemampuan berpikir kritis. Angket digunakan untuk mengetahui kategori gaya belajar siswa. Sedangkan tes tertulis digunakan untuk memperoleh deskripsi kemampuan berpikir kritis siswa saat menyelesaikan masalah. Sedangkan teknik non tes yang digunakna adalah wawancara yang digunakan untuk memperoleh kredibilitas data.

Analisis data yang digunakan meliputi reduksi data, penyajian data, dan penarikan kesimpulan. Reduksi data yang digunakan adalah merangkum dan memfokuskan hal-hal yang pokok, mencari hal-hal yang penting, dan membuang yang tidak perlu. Sehingga data yang telah di reduksi akan mempermudah dalam melakukan pengumpulan data berikutnya. Penyajian data yang digunakan adalah menjabarkan dengan teks naratifyang digabungkan agar informasi yang diperoleh tersusun dan mudah dipahami. Penarikan simpulan dan verifikasi dengan memperhatikan hasil tes menggunakan kuisioner untuk menentukan siswa tersebut masuk ke dalam kelompok gaya belajar Visual, Auditori, atau Kinestetik. Selain itu, peneliti melakukan triangulasi hasil tes kemampuan berpikir kritis dan wawancara untuk menarik kesimpulan sebagai narasi profil kemampuan berpikir kritis subjek penelitian berdasarkan kategori gaya belajar yang mereka miliki.

Berikut ini adalah tahapan kemamapuan berpikir kritis yang dirujuk dari Siswono [10] dapat dilihat pada tabel 1 .

TABEL 1 Tahapan Kemampuan Berpikir Kritis

\begin{tabular}{cc}
\hline Tahapan & Indikator \\
\hline $\begin{array}{c}\text { Elementary Clarification (Penjelasan } \\
\text { Sederhana) }\end{array}$ & Menuliskan informasi yang diketahui \\
& $\begin{array}{c}\text { Menuliskan yang } \\
\text { ditanya }\end{array}$
\end{tabular}


Basic Support (KeterampilanDasar)

Memisalkan

permasalahan

Menuliskan sumber/ rumus

Inference (Kesimpulan)

Strategy and Tactic (Strategi dan Taktik)

Menyimpulkan

Memadukan

\section{Hasil dan Pembahasan}

\subsection{Hasil}

Penentuan gaya belajar siswa melalui pengisian instrumen angket gaya belajar yang dilakukan oleh siswa, sehingga diperoleh data yang dijabarkan pada tabel 2.

TABEL 2 Prosentase Gaya Belajar Siswa Kelas VIII E

\begin{tabular}{ccc}
\hline Gaya Belajar Siswa & Banyak Siswa & Presentase (\%) \\
\hline Visual & 5 & 17,86 \\
Auditori & 15 & 53,57 \\
Kinestetik & 8 & 28,57 \\
\hline
\end{tabular}

Kemudian dari setiap kelompok untuk setiap gaya belajarnya diambil satu subjek yang dijadikan sebagai subjek penelitian. Dari 28 responden, masing-masing siswa mempunyai gaya belajar yang berbeda-beda, yang nantinya akan dipilih 3 skor tes tertinggi dari masing-masing gaya belajar Visual, Auditori, dan Kinestetik. Penentuan subjek masing-masing gaya belajar tidak mutlak, hanya berkecenderungan. Oleh karena itu, peneliti memilih siswa yang memiliki kecenderungan kuat di antara ketiga gaya belajar tersebut. Peneliti memilih siswa yang memiliki kemampuan akademik yang setara dan komunikatif, sehingga terpilih 3 siswa yaitu subjek gaya belajar Visual (S-V1), subjek gaya belajar Auditori (S-A1), dan subjek gaya belajar Kinestetik (S-K1) sebagai subjek penelitian. Adapun skor angket subjek yang terpilih bedasarkan gaya belajar dijabarkan dalam tabel 3 . 
TABEL 3 Subjek Penelitian

\begin{tabular}{ccc}
\hline Gaya Belajar Siswa & Kode Subjek & Skor \\
\hline Visual & S-V1 & 35 \\
Auditori & S-A1 & 44 \\
Kinestetik & S-K1 & 37
\end{tabular}

Setelah mendapatkan subjek terpilih seperti yang ditampilkan pada tabel 2, selanjutnya dilakukan tes penyelesaian masalah SPLDV yang sudah divalidasi oleh dosen pendidikan matematika. Setelah siswa mengerjakan tes yang diberikan, peneliti mewawancarai ketiga subjek terpilih. Kemudian, peneliti menganalisis data kemampuan berpikir kritis, data wawancara, dan hasil triangulasi data ketiga subjek.

Berikut satu contoh soal yang diberikan: enam tahun yang lalu umur Sinta empat kali umur Ayu. Sekarang umur Sinta dua kali umur Ayu. Berapa jumlah umur Ayu dan Sinta enam tahun yang akan datang?

\subsubsection{Analisis Kemampuan Berpikir Kritis yang Ditinjau dari Gaya Belajar Visual}

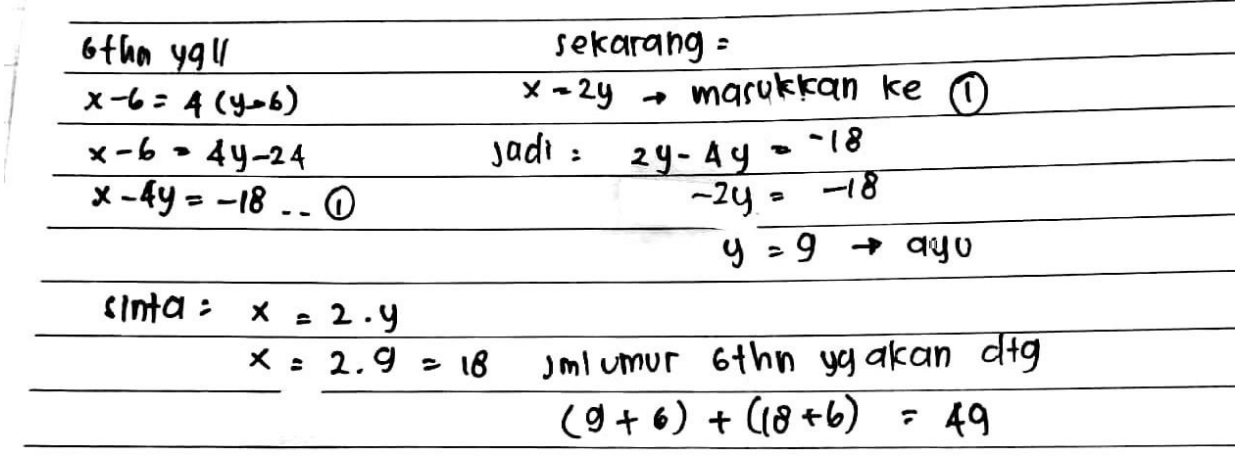

\section{Gambar 1 Pekerjaan Subjek S-V1}

Subjek Visual menuliskan secara runtut penyelesaian dari permasalahan yang diberikan (lihat gambar 1). Adapun hasil pekerjaan subjek S-V1, dikonfirmasi dengan kutipan wawancara peneliti dengan subjek S-V1 disajikan sebagai berikut. Skrip 1. Kutipan wawancara peneliti dengan subjek S-V1. 
$\mathrm{P} \quad$ : Apa yang diketahui pada soal?

S-V1 : Umur sinta enam tahun yang lalu adalah $\mathrm{x}-6$ dan umur ayu enam tahun yang lalu adalah $\mathrm{y}-6$, umur sinta enam tahun yang akan datang adalah $\mathrm{x}$ +6 dan umur ayu enam tahun yang akan datang adalah y +6 .

$\mathrm{P} \quad$ : Lanjut, apa yang ditanyakan pada soal?

S-V1 : Jumlah umur ayu dan sinta enam tahun yang akan datang.

$\mathrm{P} \quad$ : Kalo variabel yang kamu misalkan di soal apa saja?

S-V1 : Sinta sama ayu.

$\mathrm{P} \quad$ : Bagaimana kamu bisa mendapatkan jawaban tersebut?

S-V1 : Itu aku sedikit lupa caranya hehe.

$\mathrm{P} \quad$ : Tapi itu ketemu hasilnya dek, menggunakan cara dari siapa?

S-V1 : Iya awalnya lupa, terus inget pernah juga dikasih soal agak mirip kaya gitu.

$\mathrm{P} \quad$ : Soal dari siapa?

S-V1 : Dari guru matematika di sekolah mbak, tapi agak lupa mbak hehe.

$\mathrm{P} \quad$ : Apa kesimpulan yang diperoleh dari soal?

S-V1 : Jumlah umur sinta dan ayu 6 tahun yang akan datang 49 mbak.

$\mathrm{P} \quad$ : Yakin dengan jawabanmu?

S-V1 : InsyaAllah yakin.

$\mathrm{P}$ : Coba dihitung ulang kesimpulannya.

S-V1 : Oya salah mbak hehe.

$\mathrm{P} \quad$ : Berapa hasilnya?

S-V1 : 39 tahun.

$\mathrm{P} \quad$ : Diteliti lagi ya.

Dari hasil pekerjaan subjek S-V1, kemudian ditentukan indikator kemampuan berpikir kritis yang dicapai dan ditriangulasikan dengan hasil wawancara subjek S-V1. Adapun hasil analisis data terhadap subjek S-V1 disajikan pada tabel 4 .

TABEL 4 Analisis kemampuan berpikir kritis subjek S-V1

\begin{tabular}{ccccc}
\hline Tahapan & Indikator & Tes & Wawancara & Simpulan \\
\hline & Menuliskan informasi yang & Tidak & Mampu & Tidak \\
Elementary Clarification & diketahui & Mampu & & Mampu \\
(Penjelasan Sederhana) & Menuliskan yang & Tidak & & Tidak \\
& ditanya & Mampu & Mampu & Mampu \\
& Memisalkan & Tidak & Mampu & Tidak \\
& permasalahan & Mampu & & Mampu \\
Basic Support (Keterampilan & & & & \\
Dasar) & Menuliskan sumber/ rumus & Mampu & Mampu & Mampu \\
& & Kurang & Kurang & Kurang \\
Inference (Kesimpulan) & Menyimpulkan & Mampu & Mampu & Mampu \\
Strategy and Tactic (Strategi & & Tidak & Mampu & Mampu \\
dan Taktik) & Memadukan & Mampu & Mampu
\end{tabular}




\subsubsection{Analisis Kemampuan Berpikir Kritis yang Ditinjau dari Gaya Belajar Audiorial}

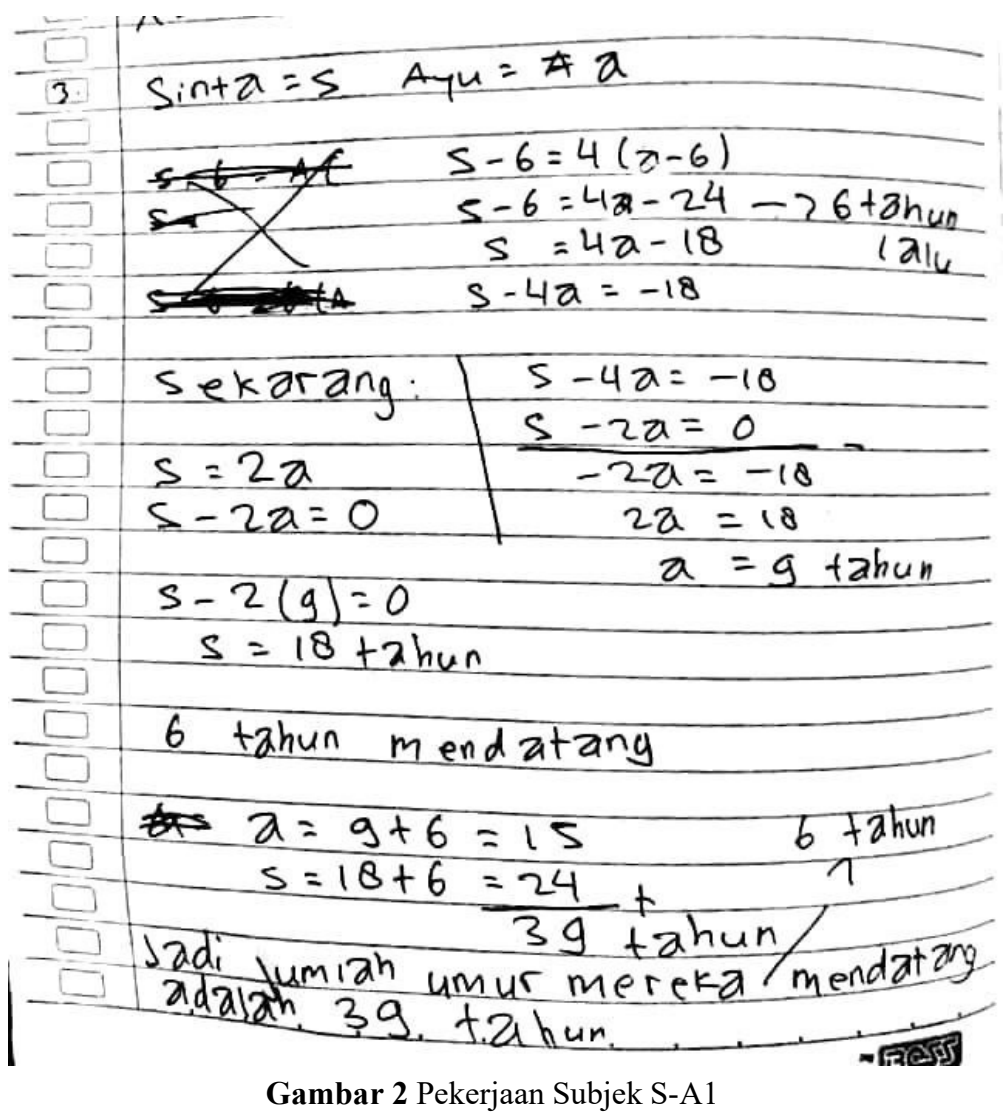

Adapun hasil pekerjaan subjek S-A1 dikonfirmasi melalui kutipan wawancara peneliti dengan subjek S-A1 disajikan sebagai berikut.

Skrip 2. Kutipan wawancra peneliti dengan subjek S-A1 


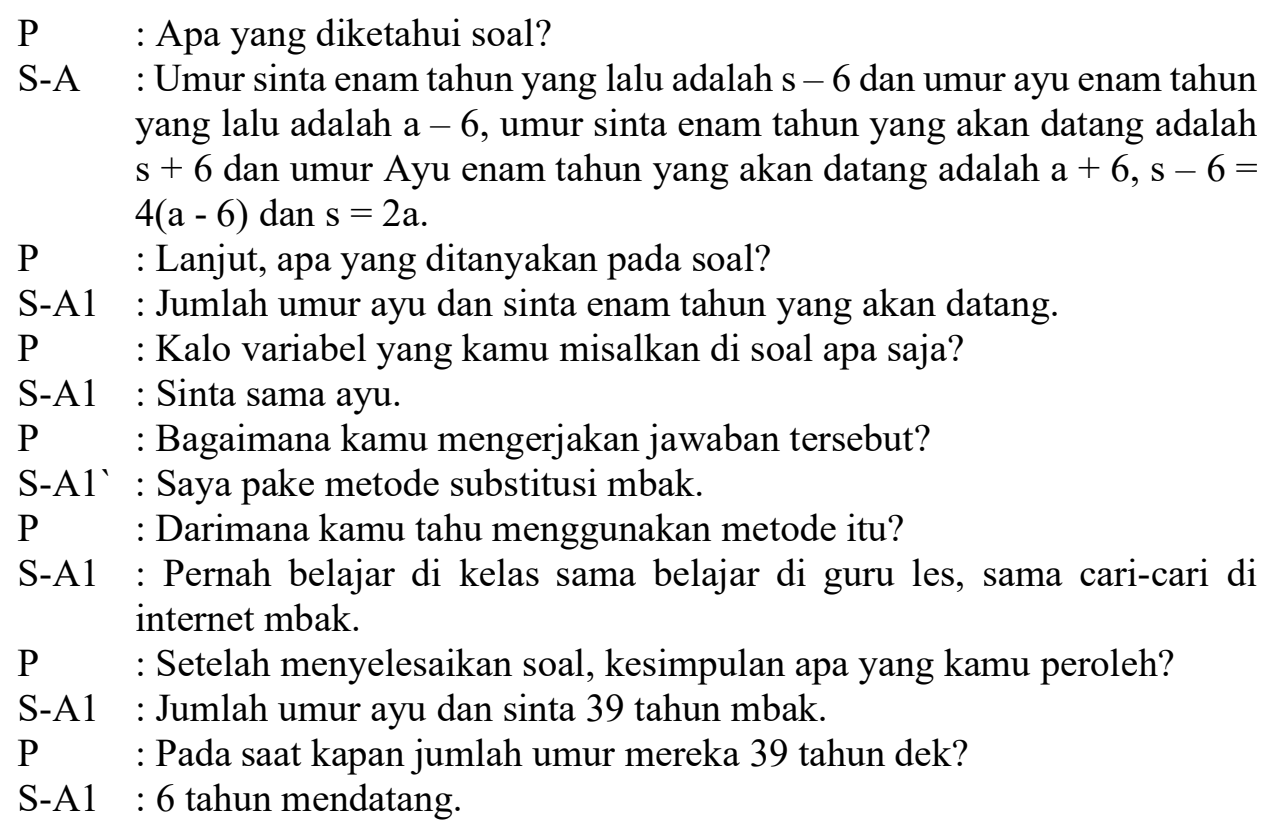

Dari hasil pekerjaan subjek S-A1 tersebut, kemudian ditentukan indikator kemampuan berpikir kritis yang dicapai dan ditriangulasikan dengan hasil wawancara subjek S-A1. Berikut hasil analisis data terhadap subjek S-A1.

TABEL 5 Analisis Kemampuan Berpikir Kritis Subjek S-A1

\begin{tabular}{ccccc}
\hline Tahapan & Indikator & Tes & Wawancara & Simpulan \\
\hline $\begin{array}{c}\text { Menuliskan } \\
\text { informasi yang } \\
\text { diketahui } \\
\text { (Penjelasan } \\
\text { Sederhana) }\end{array}$ & Tidak Mampu & Mampu & Tidak Mampu \\
& $\begin{array}{c}\text { Menuliskan yang } \\
\text { ditanya } \\
\text { Memisalkan } \\
\text { permasalahan }\end{array}$ & Tidak Mampu & Mampu & Tidak Mampu \\
& $\begin{array}{c}\text { Menuliskan } \\
\text { Basic Support (Keterampilan Dasar) }\end{array}$ & Mampu & Mampu \\
sumfer/ rumus & Mampu & Mampu & Mampu \\
Strategy and Tactic & Menyimpulkan & Mampu & Mampu & Mampu \\
(Strategi dan Taktik) & Memadukan & Tidak Mampu & Mampu & Tidak Mampu \\
\hline
\end{tabular}




\subsubsection{Analisis Kemampuan Berpikir Kritis yang Ditinjau dari Gaya Belajar Kinestetik}

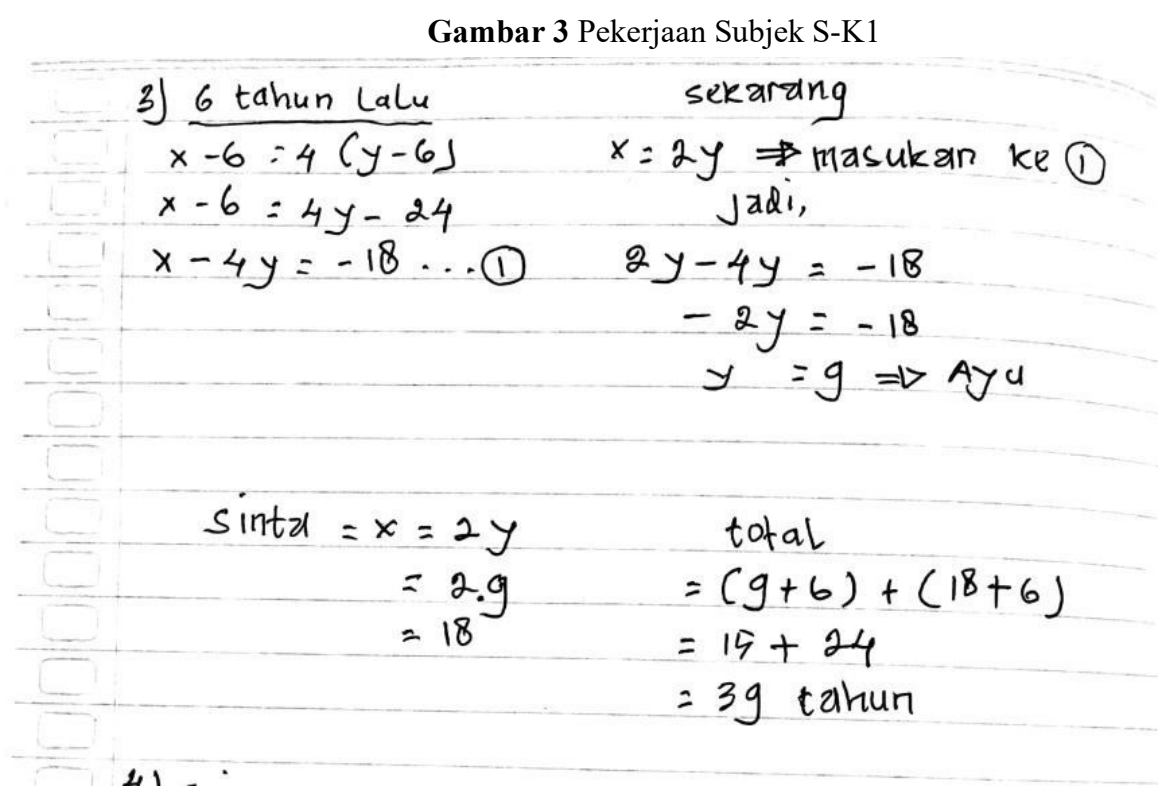

Terkait dengan hasil pekerjaan subjek S-K1, kutipan wawancara peneliti dengan subjek SK1 disajikan sebagai berikut.

Skrip 3. Kutipan wawancara peneliti dengan subjek S-K1

$\mathrm{P} \quad$ : Apa yang diketahui pada soal?

S-K1 : Umur sinta 6 tahun yang lalu adalah $\mathrm{x}-6$ dan umur ayu 6 tahun yang lalu adalah $\mathrm{y}-6$, umur sinta sekarang itu $\mathrm{x}$ dan umur ayu sekarang $\mathrm{y}$, umur sinta 6 tahun yang lalu adalah 4 kali umur ayu pada saat 6 tahun yang lalu juga, di lembar jawab aku tulis $x-6=4(y-6)$ terus umur sinta sekarang itu 2 kali umur ayu, disitu aku tulis $x=2 y$.

$\mathrm{P} \quad$ : Lanjut, apa yang ditanyakan pada soal?

S-K1 : Jumlah umur ayu dan sinta enam tahun yang akan datang.

$\mathrm{P} \quad$ : Kalo variabel yang kamu misalkan di soal apa saja?

S-K1 : Aku misalkan sinta sama ayu.

$\mathrm{P} \quad$ : Kenapa tidak ditulis permisalannya? Itu $\mathrm{x}$ siapa, y siapa, kan mbak tidak tahu.

S-K1 : Oya lupa mbak hehe.

$\mathrm{P} \quad$ : Oke. Sebelumnya sudah pernah belajar soal seperti ini?

S-K1 : Sudah mbak, pas pelajaran matematika di sekolah.

$\mathrm{P} \quad$ : Setelah menyelesaikan soal, kesimpulan apa yang kamu peroleh?

S-K1 : Jumlah umur sinta dan ayu 6 tahun yang akan datang adalah 39 tahun.

Dari hasil pekerjaan subjek S-K1 tersebut, kemudian ditentukan indikator kemampuan berpikir kritis yang dicapai dan ditriangulasikan dengan hasil wawancara subjek S-K1. Berikut hasil analisis data terhadap subjek S-K1. 
TABEL 6 Analisis Kemampuan Berpikir Kritis Subjek S-K1

\begin{tabular}{ccccc}
\hline Tahapan & Indikator & Tes & Wawancara & Simpulan \\
\hline & $\begin{array}{c}\text { Menuliskan informasi yang } \\
\text { diketahui }\end{array}$ & Tidak Mampu & Mampu & Tidak Mampu \\
& & & & \\
Elementary Clarification & Menuliskan yang & Tidak & Mampu & Tidak \\
(Penjelasan & ditanya & Mampu & & Mampu \\
Sederhana) & Memisalkan & Tidak & Mampu & Tidak \\
& permasalahan & Mampu & & Mampu \\
& Menuliskan sumber/ rumus & & & Mampu \\
Basic Support & & Mampu & Mampu & Tidak \\
(Keterampilan Dasar) & Menyimpulkan & Tidak & Mampu & Mampu \\
Inference & Memadukan & Tidak & Mampu & Tidak \\
(Kesimpulan) & & Mampu & & Mampu \\
\hline Strategy and Tactic & Strategi dan Taktik) & & &
\end{tabular}

\subsection{Pembahasan}

Berdasarkan hasil penelitian yang telah dikemukakan, maka pada bagian ini akan dikemukakan pembahasan hasil penelitian berdasarkan hasil analisis deskriptif.

\subsubsection{Deskripsi Kemampuan Berpikir Kritis yang Ditinjau dari Gaya Belajar Visual}

Siswa dengan gaya belajar Visual dalam menyelesaikan masalah matematika mampu mencapai 2 tahapan berpikir kritis, yaitu tahap keterampilan dasar (basic support) dan tahap kesimpulan (inference) dengan benar, namun kurang lengkap.

Siswa Visual kurang dalam menjelaskan informasi apa saja yang dibutuhkan saat menyelesaikan masalah dimana tahap ini termasuk tahap penjelasan sederhana (elementary clarification). Pada tahap keterampilan dasar (basic support) dengan indikator menuliskan sumber/ rumus, subjek mampu menuliskan penyelesaian dengan benar dan lengkap. Subjek mendapatkan sumber dengan pengalaman di kelas yang pernah disampaikan oleh guru matematika. Namun ada sedikit kendala pada saat wawancara, subjek masih kurang memahami dengan hasil penyelesaiannya, dengan alasan lupa dan bingung. Tahap kesimpulan (inference), subjek mampu menuliskan kesimpulan, tetapi kurang teliti dalam menghitung pada hasil akhir. Pada saat wawancara, subjek kurang mampu menyebutkan kesimpulan pada soal tes penyelesaian masalah matematika dengan lancar.

Dalam tahap ini terdapat 3 indikator diantaranya, menuliskan informasi yang diketahui, menuliskan yang ditanyakan, dan memisalkan permasalahan. Dari 3 indikator tersebut, subjek tidak menuliskan informasi apapun mengenai informasi yang mendukung penyelesaian masalah. Hal ini sesuai dengan hasil penelitian yangdilakukan oleh Setyawan, dkk [13] mengatakan bahwa siswa dengan gaya belajar Visual lebih memilih representasi berbentuk diagram dibandingkan dengan menulisnya daam bentuk simbol maupun kata-kata.

Pada tahap strategi dan teknik (strategy and tactic), subjek tidak mampumemadukan hasil yang diperoleh dari tahapan sebelumnya. Subjek belum mampu menuliskan dan menyebutkan dengan spesifik langkah-langkah dalam menyelesaikan masalah yang diberikan. Artinya, subjek dengan gaya belajar Visual belum mampu memahami materi/ konsep yang diajarkan dengan baik. Hal ini sejalan dengan penelitian oleh Zahroh [14] yang mengatakan bahwa pada tahap memahami konsep/ masalah subjek dengan gaya belajar Visual hanyamampu membaca informasi saja. Subjek hanya mampu menyelesaikan soal dengan perhitungan maupun menyelesaikan soal yang hampir sama dengan contoh yang diberikan oleh guru. Dengan demikian, siswa dengan gaya belajar Visual belum memenuhi semua indikator dari masing- 
masing tahapan berpikir kritis. Jadi dapat dikatakan subjek belum mempunyai kemampuan berpikir kritis yang baik.

\subsubsection{Deskripsi Kemampuan Berpikir Kritis yang Ditinjau dari Gaya Belajar Auditori}

Siswa dengan gaya belajar Auditori dalam menyelesaikan masalah matematika mampu mencapai 2 tahapan berpikir kritis dengan benar dan tepat, yaitu tahap membangun keterampilan dasar (basic support) dan tahap kesimpulan (inference).

Sama halnya dengan subjek Visual, untuk tahap memberikan penjelasan sederhana (elementary clarification), subjek belum dikatakan mampu mencapai tahap memberikan penjelasan sedarhana, karena subjek hanya mampu mencapai 1 indikator dari 3 indikator. Sedangkan di tahap ini, untuk mencapai tahap berpikir kritis ada 3 indikator yang harus dicapai diantaranya mampu menuliskan yang diketahui, mampu menuliskan yang ditanya, dan mampu memisalkan permasalahan. Tahap membangun keterampilan dasar (basic support), subjek mampu menuliskan sumber/ rumus dengan sangat baik. Hal ini dikarenakan, subjek dengan gaya belajar Auditori mampu mengingat apa yang pernah didiskusikan sebelumnya. Subjek mempunyai inisiatif untuk mencarisumber dengan mengingat pembelajaran saat di dalam kelas maupun di luarkelas seperti tempat les privat.

Tahap kesimpulan (inference), subjek mampu menuliskan kesimpulan dengan benar dan tepat. Artinya, subjek dengan gaya belajar Auditori mampu mengevaluasi setiap hasil pekerjaannya agar hasil akhir yang diperoleh benar dan tepat. Sebagaimana diugkapkan oleh Scriven dan Paul dalam Karim [5] mengungkapkan bahwa berpikir kritis adalah proses intelektual yang dengan aktif menganalisis, mengevaluasi informasi yang dikumpulkan atau dihasilkan dari pengamatan maupun pengalaman.

Tahap strategi dan teknik (strategy and tactic), subjek juga belum dikatakan mampu memadukan hasil yang diperoleh dari tahapan sebelumnya. Subjek belum mampu menuliskan dan menyebutkan dengan spesifik langkah-langkah dalam menyelesaikan masalah yang diberikan dari awal hingga akhir.

Dengan demikian, siswa dengan gaya belajar auditori belum memenuhi semua indikator dari masing-masing tahapan berpikir kritis. Jadi dapat dikatakan subjek belum mempunyai kemampuan berpikir kritis yang baik, namun siswa dengan gaya belajar Auditori mempunyai kemampuan berpikir kritis lebih baik dibandingkan siswa dengan gaya belajar Visual dan Kinestetik. Hal ini sejalan dengan penelitian terdahulu yang dilakukan oleh Safitri, dkk [15] yang mengatakan bahwa siswa gaya belajar Auditori memiliki kemampuan berpikir kritis lebih baik dibandingkan siswa dengan gaya belajar Visual dan Kinestetik.

\subsubsection{Deskripsi Kemampuan Berpikir Kritis yang Ditinjau dari Gaya Belajar Kinestetik}

Siswa dengan gaya belajar Kinestetik dalam menyelesaikan masalah matematika hanya mampu mencapai 1 tahapan berpikir kritis yaitu tahap keterampilan dasar (basic support).

Sama halnya dengan subjek gaya belajar auditori, untuk tahap memberikan penjelasan sederhana (elementary clarification), subjek hanya mampu menuliskan permisalan masalah yang akan didiskusikan, subjek belum mampu menuliskan indikator yang diketahui dan ditanyakan dalam permasalahan. Subjek gaya belajar Kinestetik masih kurang teliti, tidak memisalkan permasalahan dengan alasan lupa. Tahap membangun keterampilan dasar (basic support), subjek mampu menuliskan sumber/ rumus dengan baik.

Tahap kesimpulan (inference), subjek belum mampu menuliskan kesimpulan dengan baik. Artinya, subjek dengan gaya belajar kinestetik belum mampu mengevaluasi setiap hasil pekerjaannya. Tahap strategi dan teknik (strategy and tactic), subjek tidak mampu memadukan/ menyesuaikan hasil pekerjaannya, subjek hanya berpacu dengan sumber/ materi yang disampaikan guru di sekolah. Pada saat wawancara sesuai dengan salah satu ciri-ciri gaya belajar kinestetik, subjek mampu menjelaskan langkah- langkah menyelesaikan masalah 
dengan cara pelan, namun pasti. Ada sedikit kendala saat menjelaskan langkah-langkahnya dikarenakan lupa. Artinya, subjek belum mampu memahami konsep yang diajarkan. Subjek cenderung menggunakan satu cara untuk menyelesaikan masalah matematika yang bersumber dari guru.

Dengan demikian, siswa dengan gaya belajar kinestetik belum memenuhi semua indikator dari masing-masing tahapan berpikir kritis. Jadi dapat dikatakan subjek belum mempunyai kemampuan berpikir kritis yang baik, siswa dengan gaya belajar kinestetik hanya mampu mencapai satu tahapan berpikir kritis yaitu tahap keterampilan dasar (basic support). Siswa dengan gaya belajar Kinestetik termasuk siswa yang paling kurang kritis dibandingkan dengan kedua gaya belajar lainnya. Hal ini sesuai dengan penelitian yang dilakukan oleh Safitri, dkk [15] mengatakan bahwa siswa dengan gaya belajar kinestetik kurang memiliki kemampuan berpikir kritis dibandingkan siswa dengan gaya belajar Visual dan auditori.

\subsubsection{Faktor yang Mempengaruhi Kemampuan Berpikir Kritis Siswa}

Dalam menyelesaikan permasalahan matematika, faktor-faktor yang mempengaruhi lemahnya kemampuan berpikir kritis siswa diantaranya sebagai berikut.

a. Siswa kurang terbiasa mengerjakan soal-soal yang membutuhkan kemampuan berpikir kritis sehingga siswa kurang mampu memahami soal. Hal ini sejalan dengan kajian yang dilakukan oleh Fatmawati, dkk [16] yang mengatakan bahwa faktor yang mempengaruhi proses berpikir kritis dalam menyelesaikan soal pemecahan masalah salah satunya adalah siswa tidak terbiasa mengerjakan soal dalam bentuk soal cerita. Selain itu, siswa kurang mampu memahami maksud soal. Hal ini menyebabkan siswa tidak mampu mengubah soal cerita ke dalam bentuk matematika dan merasa kesulitan dalam menyelesaikan soal. Penemuan ini didukung dari hasil pnelitian dimana siswa kesulitan dalam menjelaskan informasi yang dibutuhkan pada tahap penjelasan sederhana (elementary clarification). Selain itu, pengambilan subjek dengan kemampuan matematika sedang dan rendah ditemukan mengalami kesulitan dalam memecahkan masalah yang diberikan [17].

b. Gaya belajar yang digunakan siswa. Untuk meningkatkan kemampuan berpikir kritis siswa, guru harus mampu menyampaikan pembelajaran yang menarik untuk membangun pemahaman dan mendorong ide-ide yang dimiliki siswa. Dalam membangun pemahaman tersebut dipengaruhi gaya belajar yang dimiliki oleh masing-masing siswa. Hal ini sesuai dengan kajian terdahulu yang dilakukan oleh Karim [5] mengatakan bahwa setiap siswa mempunyai gaya belajar yang berbeda. Oleh karena itu, guru harus memiliki kreativitas dalam menyampaikan materi pelajaran agar dapat menciptakan prose belajar mengajar yang menyenangkan bagi siswa.

c. Siswa cenderung hanya menggunakan satu cara untuk menyelesaikan masalah matematika yang bersumber dari guru. Siswa belum mampu mencari solusi lain dari suatu permasalahan. Sumber belajar siswa hanya terpaku dari contoh yang diberikan oleh guru. Siswa akan merasa kesulitan jika bentuk soal diubah menjadi tipe yang berbeda. Hal ini sesuai dengan penelitian sebelumnya yang dilakukan oleh Fatmawati, dkk [16] mengatakan bahwa faktor yang mempengaruhi proses berpikir kritis dalam menyelesaikan soal pemecahan masalah adalah siswa cenderung hanya menggunakan satu cara dan berhenti setelah menemukan solusi dari permasalahan tersebut sehingga siswa juga sering tidak mengecek hasil pekerjaannya setelah selesai dikerjakan.

Selain itu, kajian mengenai faktor-faktor yang mempengaruhi kemampuan berpikir kritis siswa merupakan kajian yang masih sangat relevan untuk mempertimbangkan perbaikan dan pengembangan instrumen pembelajaran [18]. Hal ini dikarenakan deskripsi yang diperoleh dari masing-masing subjek (ditinjau dari gaya belajar) memiliki karakteristik yang berbeda saat 
menyelesaikan permasalahan yang diberikan. Selain ditinjau dari gaya belajar siswa, kemampuan berpikir kritis siswa dapat dikaji dari faktor-faktor lain. Peneliti merekomendasikan beberapa kajian mengenai faktor yang mempengaruhi kemampuan berpikir kritis siswa ditinjau tidak hanya dari gaya belajar saja namun juga kemampuan matematika, minat, dan motivasi siswa [19], [20]. Dengan adanya penelitian mengenai faktor gaya belajar sebagai salah satu kajian diharapkan dapat memberikan kontribusi kepada guru untuk mempertimbangkan tahapan berpikir kritis siswa ditinjau dari gaya belajar yang mereka miliki.

\section{Kesimpulan}

Berdasarkan hasil penelitian dan pembahasan, maka dapat disimpulkan bahwa (1) siswa dengan gaya belajar Visual mampu mencapai dua tahapan berpikir kritis dengan benar, namun sedikit kurang lengkap yaitu tahap membangun keterampilan dasar (basic support) dan tahap kesimpulan (inference), (2) siswa dengan gaya belajar auditori mampu mencapai 2 tahapan berpikir kritis dengan benar dan tepat yaitu tahap membangun keterampilan dasar (basic support) dan tahap kesimpulan (inference), (3) siswa dengan gaya belajar Kinestetik hanya mampu mencapai satu tahapan berpikir kritis yaitu tahap keterampilan dasar (basic support), dan (4) faktor yang mempengaruhi kemampuan berpikir kritis siswa dalam menyelesaikan masalah matematika yaitu lemahnya kemampuan dalam menyelesaikan soal yang berhubungan dengan soal cerita, gaya belajar dan kecenderungan siswa yang hanya menggunakan satu cara untuk menyelesaikan masalah matematika yang bersumber dari guru.

\section{Daftar Pustaka}

[1] A. A. Nugroho, R. W. Y. Putra, F. G. Putra, and M. Syazali, "Pengembangan Blog Sebagai Media Pembelajaran Matematika," Al-Jabar J. Pendidik. Mat., vol. 8, no. 2, pp. 197-203, Dec. 2017.

[2] A. Rahayunigrum, F. Setyawan, and U. Khasanah, "Profil Pemecahan Masalah Pada Materi Persamaan Linier Satu Variabel Dengan Menggunakan Pendekatan Model Eliciting Activities (MEAs) Dilihat Dari Kemampuan Matematika," Alphamath, vol. 4, no. 1, pp. 15-22, 2018.

[3] S. Andriani, "Evaluasi CSE-UCLA pada Studi Proses Pembelajaran Matematika," AlJabar J. Pendidik. Mat., vol. 6, no. 2, pp. 167-176, Dec. 2015.

[4] R. Febriano, S. Sugiatno, and D. Suratman, "Kemampuan Berpikir Kritis Matematis Dikaji dari Students Belief dalam Materi SPLDV di SMP," J. Pendidik. dan Pembelajaran Khatulistiwa, vol. 8, no. 5, May 2019.

[5] A. Karim, "Pengaruh Gaya Belajar dan Sikap Siswa pada Pelajaran Matematika Terhadap Kemampuan Berpikir Kritis Matematika," Form. J. Ilm. Pendidik. MIPA, vol. 4, no. 3, pp. 188-195, Aug. 2015.

[6] N. P. Irianti, S. Subanji, and T. D. Chandra, "Proses Berpikir Siswa Quitter dalam Menyelesaikan Masalah SPLDV Berdasarkan Langkah-langkah Polya," JMPM J. Mat. dan Pendidik. Mat., vol. 1, no. 2, p. 133, Sep. 2016.

[7] R. Rosmaiyadi, "Analisis Kemampuan Berpikir Kritis Matematis Siswa dalam Learning Cycle 7E Berdasarkan Gaya Belajar," AKSIOMA J. Progr. Stud. Pendidik. Mat., vol. 6, no. 1, p. 12, Jun. 2017.

[8] F. Setyawan, "Profil Representasi Siswa SMP terhadap Materi PLSV Ditinjau dari Gaya Belajar KOLB," J. Medives, vol. 1, no. 2, pp. 82-90, 2017.

[9] A. K. Sari, "Analisis Karakteristik Gaya Belajar VAK (Visual, Auditori, Kinestetik) Mahasiswa Pendidikan Informatika Angkatan 2014," Edutic - Sci. J. Informatics Educ., vol. 1, no. 1, Nov. 2014.

[10] T. Y. E. Siswono, Pembelajaran Matematika Berbasis Pengajuan dan Pemecahan Masalah, Fokus Pada Berpikir Kritis dan Berpikir Kreatif. Bandung: PT. Remaja Rosdakarya, 2018.

[11] Sugiyono, Metode Penelitian Pendekatan Kuantitatif, Kualitatif, dan R\&D. Bandung: Alfabeta, 2018.

[12] Sugiyono, Metode Penelitian Pendekatan Kuantitatif, Kualitatif, dan R\&D. Bandung: 
Alfabeta, 2015.

[13] F. Setyawan, R. C. I. Prahmana, A. Istiandaru, and A. Hendroanto, "Visualizer's representation in functions," in Journal of Physics: Conference Series, 2018, vol. 943, no. 1, p. 12004.

[14] U. Zahroh, D. B. Asyhar, J. T. Matematika, and I. Tulungagung, "Kecenderungan Gaya Belajar Mahasiswa dalam Menyelesaikan Masalah Fungsi Bijektif," J. Kebijak. dan Pengemb. Pendidik., vol. 2, no. 1, pp. 72-81, Feb. 2014.

[15] S. Rokhimah and S. Rejeki, "Kemampuan Berpikir Kritis Siswa Berdasarkan Gaya Belajar pada Pembelajaran dengan Model 4K," Kontinu J. Penelit. Didakt. Mat., vol. 2, no. 1, p. 1, Oct. 2018.

[16] H. Fatmawati, M. Mardiyana, and T. Triyanto, “Analisis Berpikir Kritis Siswa Dalam Pemecahan Masalah Matematika Berdasarkan Polya pada Pokok Bahasan Persamaan Kuadrat (Penelitian pada Siswa Kelas X SMK Muhammadiyah 1 Sragen Tahun Pelajaran 2013/2014)," J. Pembelajaran Mat., vol. 2, no. 9, pp. 899-910, Nov. 2014.

[17] E. U. Ani and P. Rahayu, "Profil Kemampuan Pemecahan Masalah Matematika Siswa Berbentuk Soal Cerita Materi Bangun Ruang," J. Ris. Pendidik. dan Inov. Pembelajaran Mat., vol. 1, no. 1, p. 40, May 2018.

[18] F. Setyawan, P. W. Prasetyo, and B. A. Nurnugroho, "Developing complex analysis textbook to enhance students' critical thinking," JRAMathEdu (Journal Res. Adv. Math. Educ., vol. 5, no. 1, pp. 26-37, Feb. 2020.

[19] L. S. Zanthy, "Pengaruh Motivasi Belajar Ditinjau dari Latar Belakang Pilihan Jurusan terhadap Kemampuan Berpikir Kritis Mahasiswa Di STKIP Siliwangi Bandung," TEOREMA Teor. dan Ris. Mat., vol. 1, no. 1, pp. 47-54, Sep. 2016.

[20] N. R. Prihartiwi, D. Hidayat, and A. W. Kohar, "Analisis Kemampuan Berpikir Kritis Mahasiswa dalam Membuat Prediksi Berdasarkan Grafik," GAUSS J. Pendidik. Mat., vol. 03, no. 02, pp. 43-54, Dec. 2020. 